\title{
Studies on the Mechanism of Intrinsic Resistance to $\beta$-Lactam Antibiotics in Group D Streptococci
}

\author{
By RUSSELL WILLIAMSON, ${ }^{1}$ STEPHEN B. CALDERWOOD, ${ }^{2}$ \\ ROBERT C. MOELLERING, $\mathbf{J}^{2}$ AND ALEXANDER TOMASZ ${ }^{*} *$ \\ ${ }^{1}$ The Rockefeller University, New York, New York 10021, U.S.A. \\ ${ }^{2}$ Infectious Disease Unit, Department of Medicine, Massachusetts General Hospital, Boston, \\ Massachusetts 02114, U.S.A.
}

(Received 20 April 1982; revised 4 October 1982)

\begin{abstract}
Six penicillin-binding proteins (PBPs) were detected in clinical isolates of each one of three group D streptococci: Streptococcus bovis, $S$. faecalis and $S$. faecium. When examined in whole organisms, the PBPs of $S$. faecium, the most penicillin-resistant species of group D streptococci, generally had lower affinities for the antibiotic than those of $S$. faecalis (intermediate penicillin resistance), which in turn were of lower affinity than those of $S$. bovis (penicillin-sensitive): On the other hand, no quantitative correlation could be established between the binding of penicillin to any one PBP or group of PBPs, and the penicillin MIC value for the corresponding micro-organism. Examination of the amounts of antibiotic bound and the rates of binding to PBPs of equal numbers of protoplasts and whole bacteria of $S$. faecalis and $S$. faecium, indicated that there was no permeability barrier to benzylpenicillin in the cell walls of these species. The lower antibacterial effectiveness of cephalothin compared with ampicillin in group D streptococci was paralleled by the higher concentrations of cephalothin needed in competition assays to inhibit the lower molecular size PBPs of these bacteria.
\end{abstract}

\section{INTRODUCTION}

Among streptococci, enterococci are uniquely resistant to $\beta$-lactam antibiotics, both in terms of the relatively high MIC values of the antibiotics (Toala et al., 1969) and also in the poor killing of the organisms after inhibition of growth has been achieved (Krogstad \& Parquette, 1980; Moellering et al., 1974). The mechanism of this natural resistance is unknown. Previous investigations (Weinstein \& Moellering, 1975) have indicated that the bacteria do not produce a $\beta$-lactamase. Alternative explanations of resistance include low affinities of the target sites of the antibiotics in comparison with those of other streptococci or diminished penetration to such sites.

The $\beta$-lactam antibiotics bind to membrane-associated proteins (penicillin-binding proteins, PBPs) of bacteria, and these PBPs are presumably the target sites of action, corresponding to the $\beta$-lactam antibiotic-sensitive enzymes involved in the terminal stages of peptidoglycan synthesis. The purpose of this study was to characterize the PBPs of three representative strains of group D streptococci isolated from blood cultures at the Massachusetts General Hospital. The strains were a penicillin-sensitive, non-enterococcal $S$. bovis, and two penicillin-resistant enterococci, $S$. faecalis and an $S$. faecium. The ultimate aim of the study was to determine whether the penicillin resistance of enterococci was associated with differences in PBP affinity for $\beta$-lactam antibiotics or with reduced permeability of the cell wall in comparison with the non-enterococcal group D S. bovis. The interactions of ampicillin and cephalothin with the PBPs were also examined since enterococci are substantially more resistant to cephalosporins than to ampicillin (Thornsberry et al., 1974; Moellering, 1981). 


\section{METHODS}

Bacterial strains and growth conditions. Streptococcus bovis $4054, S$. faecalis 447 , and $S$. faecium 4379 were all $\beta$ lactamase-negative clinical isolates obtained from the Massachusetts General Hospital, Boston. Identification of isolates as group D streptococci was by standard bacteriological techniques, and identification to the species level was according to the recommendations of Facklam (1972) and Gross et al. (1975). Identification of $S$. faecalis and $S$. faecium strains was confirmed by the Department of Clinical Microbiology, The New York Hospital. Stock cultures were maintained on Brucella agar slants; single colony isolates from blood agar plates, containing tryptose blood agar base (Difco) and 3\% (v/v) defibrinated sheep blood (Wilfer Laboratory, Stillwater, Minn.), were used for subsequent procedures. Bacteria were also grown without aeration at $37^{\circ} \mathrm{C}$ in dextrose phosphate broth (GIBCO Diagnostics, Madison, Wis.). Growth was monitored with a Coleman nephelometer.

Antibiotics and reagents. Ampicillin was obtained from Bristol Laboratories, Syracuse, N.Y., benzylpenicillin and cephalothin from Eli Lilly \& Co., Indianapolis, Ind., and $\left[\mathrm{para}^{-3} \mathrm{H}\right]$ benzylpenicillin, ethylpiperidinium salt (26 $\mathrm{Ci} \mathrm{mmol}^{-1}, 0.66 \mathrm{TBq} \mathrm{mmol}^{-1}$ ) from E. O. Stapley, Merck, Sharp \& Dohme, Rahway, N.J. Lysozyme was purchased from Millipore. M1-muramidase was the generous gift of K. Yokogawa, Dainippon Pharmaceutical Co. Ltd., Suita/Osaka, Japan, and was purified to homogeneity (Siegel et al., 1981). Protein molecular weight standards were purchased from Bio-Rad.

Susceptibility tests. MIC values were determined by the standard broth dilution method in dextrose phosphate broth, $\mathrm{pH} 7 \cdot 4$. The inoculum was $10^{5}$ to $10^{6} \mathrm{c.f} . \mathrm{u}$. $\mathrm{ml}^{-1}$. The lowest concentration of antibiotic preventing visible growth after overnight incubation at $37^{\circ} \mathrm{C}$ was recorded as the MIC.

Preparation of membranes. Exponential phase organisms were disrupted by sonication, and membranes recovered as previously described (Williamson et al., 1980). Protein concentrations were estimated by the Lowry method with bovine serum albumin as standard.

Analysis of penicillin-binding proteins (PBPs). Membranes (about $100 \mu \mathrm{g}$ protein) were incubated with increasing amounts $(0.03 \mathrm{ng}$ to $3.0 \mu \mathrm{g})$ of $\left[{ }^{3} \mathrm{H}\right]$ benzylpenicillin in a total volume of $50 \mu \mathrm{l} 50 \mathrm{~mm}$-sodium phosphate buffer, $\mathrm{pH} 7.0$, at $37^{\circ} \mathrm{C}$ for $10 \mathrm{~min}$. An excess of unlabelled benzylpenicillin $(600 \mu \mathrm{g})$ and $1 \%(\mathrm{w} / \mathrm{v}$, final concentration) Sarkosyl NL-97 were then immediately added to each sample. In some experiments, membranes were incubated $\left(10 \mathrm{~min}\right.$ at $\left.37^{\circ} \mathrm{C}\right)$ with various amounts of either ampicillin or cephalothin, before further incubation with saturating amounts of the radioactive benzylpenicillin $(0.32 \mu \mathrm{g}$ for $S$. bovis, and $3.2 \mu \mathrm{g}$ for $S$. faecalis and $S$. faecium). The samples were then analysed by slab SDS-PAGE (Williamson et al., 1980), except that the final concentrations $(\mathrm{w} / \mathrm{v})$ of acrylamide and $N, N^{\prime}$-bis-acrylamide in the stacking and separating gels were $3.0 \%$ and $0.036 \%$, and $6.75 \%$ and $0.081 \%$, respectively. The PBPs were detected by fluorography with exposure for $1-5 \mathrm{~d}$, as described earlier (Williamson et al., 1980) and quantitated by densitometry. The quantitative data tabulated in Tables 1 to 5 represent the mean values of three to five identical experiments.

The extent of breakdown of the benzylpenicillin-associated PBPs was measured using membranes exposed to $\left[{ }^{3} \mathrm{H}\right.$ ]benzylpenicillin for $10 \mathrm{~min}$ at $37^{\circ} \mathrm{C}, 0.32 \mu \mathrm{g}$ for $S$. bovis and $3 \cdot 2 \mu \mathrm{g}$ for $S$. faecalis and $S$. faecium; however, reaction mixtures were incubated for increasing lengths of time after addition of the unlabelled benzylpenicillin before the addition of Sarkosyl to terminate the reaction. In some experiments, either $0 \cdot 14 \mathrm{M}-2$-mercaptoethanol or $0 \cdot 2 \mathrm{M}$-hydroxylamine, $\mathrm{pH} 7 \cdot 0$, were added with the unlabelled benzylpenicillin.

Exponential phase organisms $\left(1 \mathrm{ml}\right.$, about $2 \times 10^{8}$ organisms $\left.\mathrm{ml}^{-1}\right)$ were incubated with $\left[{ }^{3} \mathrm{H}\right]$ benzylpenicillin for $10 \mathrm{~min}$ at $37^{\circ} \mathrm{C}$. An excess of unlabelled benzylpenicillin $(600 \mu \mathrm{g})$ was then added, and the samples immediately chilled in ice. Organisms were recovered by centrifugation $\left(1100 \mathrm{~g}\right.$ for $2 \mathrm{~min}$ at $\left.2^{\circ} \mathrm{C}\right)$ suspended in $50 \mu \mathrm{l}$ of $50 \mathrm{~mm}$-sodium phosphate buffer, $\mathrm{pH} \mathrm{7.0,} \mathrm{containing} 10 \mu \mathrm{g}$ lysozyme and $10 \mu \mathrm{g} \mathrm{Ml-muramidase,} \mathrm{and}$ incubated at $37^{\circ} \mathrm{C}$ for $10 \mathrm{~min}$. This resulted in complete lysis and samples were analysed as above. Lysis was not caused by either enzyme added alone. In some experiments, organisms were pretreated with various amounts of either ampicillin or cephalothin at $37^{\circ} \mathrm{C}$ for $10 \mathrm{~min}$ before the addition of saturating amounts of $\left[{ }^{3} \mathrm{H}\right]$ benzylpenicillin (3.6 $\mu \mathrm{g}$ for $S$. bovis, $4.8 \mu \mathrm{g}$ for $S$. faecalis, and $11.2 \mu \mathrm{g}$ for $S$. faecium).

To determine the availability of PBPs in whole organisms and lysed bacteria, samples $(10 \mathrm{ml})$ of exponential phase cultures (about $2 \times 10^{8}$ organisms $\mathrm{ml}^{-1}$ ) were rapidly chilled in ice and recovered by centrifugation $(12000 \mathrm{~g}$ for $5 \mathrm{~min}$ at $2{ }^{\circ} \mathrm{C}$ ). Supernates were removed by aspiration, and the bacteria resuspended in $350 \mu \mathrm{l}$ ice-cold $50 \mathrm{~mm}$ sodium phosphate buffer, $\mathrm{pH} 7 \cdot 0$, containing $2 \mathrm{M}$-sucrose, $5 \mathrm{mM}-\mathrm{MgCl}_{2}$, and $5 \mu \mathrm{g}$ DNAase. One set of samples of cell suspension (each $35 \mu \mathrm{l}$ ) received $20 \mu \mathrm{l}$ sodium phosphate buffer and was incubated at $37^{\circ} \mathrm{C}$ for $10 \mathrm{~min}$, and for a further period of $15 \mathrm{~min}$ following addition to each sample of $15 \mu$ l of one of several concentrations of $\left[{ }^{3} \mathrm{H}\right]-$ benzylpenicillin; after addition of unlabelled benzylpenicillin $(600 \mu \mathrm{g}$ in $5 \mu \mathrm{l})$ to each sample together with lysozyme $(10 \mu \mathrm{g}$ in $10 \mu \mathrm{l})$ and $\mathrm{M} 1$-muramidase $(10 \mu \mathrm{g}$ in $10 \mu \mathrm{l})$ reaction mixtures were incubated at $37^{\circ} \mathrm{C}$ for $10 \mathrm{~min}$ to lyse the organisms.

To produce protoplasts, duplicate samples of cell suspension $(35 \mu \mathrm{l})$ received lysozyme $(10 \mu \mathrm{g}$ in $10 \mu \mathrm{l})$ and $\mathrm{Ml}$ muramidase $(10 \mu \mathrm{g}$ in $10 \mu \mathrm{l})$ and were incubated at $37^{\circ} \mathrm{C}$ for $10 \mathrm{~min}$. Virtually no whole organisms were seen by phase-contrast microscopy after this procedure. The protoplast samples $(55 \mu \mathrm{l})$ were incubated at $37^{\circ} \mathrm{C}$ for $15 \mathrm{~min}$ with various amounts of $\left[{ }^{3} \mathrm{H}\right]$ benzylpenicillin $(15 \mu \mathrm{l})$, were then treated with an excess of unlabelled benzyl- 
penicillin and incubation was continued at $37^{\circ} \mathrm{C}$ for $10 \mathrm{~min}$. All samples were immediately mixed with sample dilution buffer, without glycerol, after the final incubation period, and processed for SDS-PAGE.

The rate of binding of the $\left[{ }^{3} \mathrm{H}\right]$ benzylpenicillin to the PBPs in whole organisms and protoplasts was determined using the conditions described above except that the final concentration of the radioactive antibiotic was $8.6 \mu \mathrm{g} \mathrm{ml}^{-1}$. The excess of the unlabelled benzylpenicillin $(600 \mu \mathrm{g}, 5 \mu \mathrm{l})$ was added to identical samples after $2,4,6$, 8,10 and $15 \mathrm{~min}$ incubation.

\section{RESULTS}

Six PBPs were detected in membranes from each of the three streptococcal strains, and the patterns of the PBPs were clearly different in each case (Fig. 1). When the membranes were incubated with a range of concentrations of the $\left[{ }^{3} \mathrm{H}\right]$ benzylpenicillin, the PBPs of $S$. bovis were detected at lower concentrations than those of $S$. faecalis or $S$. faecium. The MIC values $\left(\mu \mathrm{g} \mathrm{ml}^{-1}\right)$ of benzylpenicillin for the three strains were: $S$. bovis, $0.036 ; S$. faecalis, 4.8 and $S$. faecium, $37 \cdot 2$; and when the total amount of $\left[{ }^{3} \mathrm{H}\right]$ benzylpenicillin bound to the membranes was estimated (Fig. 2) there was a general trend indicating that the PBPs of S. bovis appeared to have higher affinities than those of $S$. faecalis, which in turn were higher than those of $S$. faecium. The interactions of $\left[{ }^{3} \mathrm{H}\right]$ benzylpenicillin were also examined with whole organisms and the concentration of the antibiotic required for $50 \%$ saturation $\left(\mathrm{S}_{50}\right)$ was calculated for each of the PBPs. As indicated in Table 1 , the $S_{50}$ values of individual PBPs (either in membranes or whole organisms) did not appear to correlate quantitatively with the relative resistance of each strain to the antibiotic. Only two PBPs (3 and 6) of S. bovis were detected in whole organisms of this

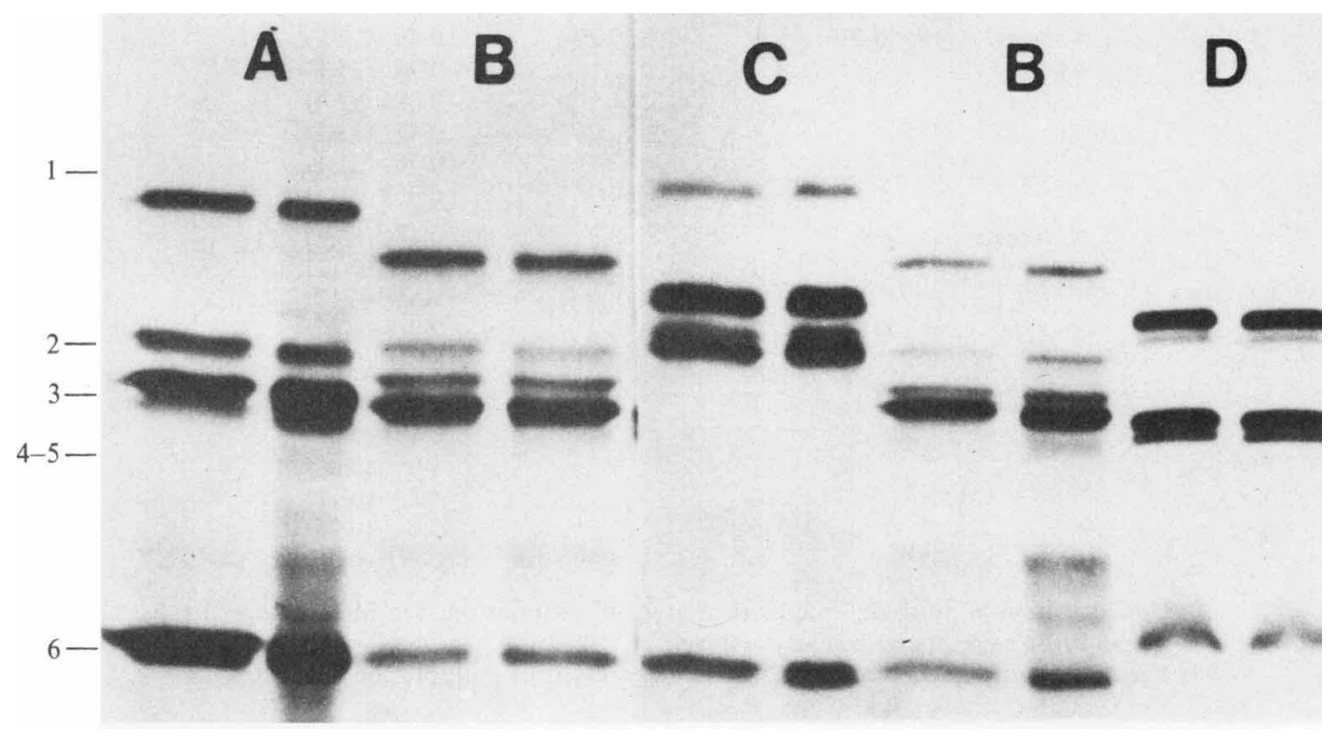

Fig. 1. Penicillin-binding proteins of group D streptococci. PBPs were labelled in whole organisms as described in Methods and applied to the gels in pairs. The left and right side sample in each pair was exposed to $1 \mathrm{ng}$ and $100 \mathrm{ng}\left[{ }^{3} \mathrm{H}\right]$ penicillin $\mathrm{ml}^{-1}$, respectively. Samples of the $S$. faecalis PBPs (B) were applied in duplicate. It is hoped that this geometric arrangement helps to compare the different relative positions of PBPs. A, S. faecium (4379); B, S. faecalis (447); C, S. bovis (4054). As reference, the PBPs of $S$. pneumoniae are also shown in D. Numbers 1 to 6 refer to the PBPs in the order of their decreasing molecular size. Molecular weight standards (Bio-Rad) were used to estimate the molecular sizes of the six PBPs of S. faecalis, which were as follows (in the order of PBP 1 to 6 ): $106000 ; 88000 ; 80000 ; 77000$; 75000 and 42000 . The molecular sizes of $S$. faecium PBPs were $126000 ; 91000 ; 86000 ; 79000 ; 77000$ and 48000 . PBP $2(91000)$ is not well visible in the Figure. The molecular size of PBP 1 of $S$. bovis was estimated at about 130000 . The fluorograms represent typical results obtained in a very large number (over 50) different experiments. 


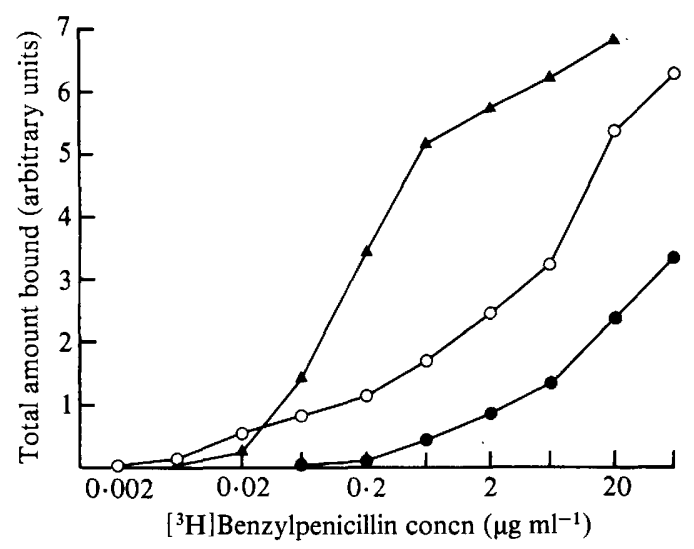

Fig. 2. Binding of $\left[{ }^{3} \mathrm{H}\right]$ benzylpenicillin to membranes. Membranes from each strain were exposed to various concentrations of $\left[{ }^{3} \mathbf{H}\right]$ benzylpenicillin as indicated in Methods. The data were derived from densitometric scanning of fluorograms. Data are from a single experiment representative of a number $(10-15)$ of separate runs.

Table 1. Affinities of PBPs for $\left[{ }^{3} \mathrm{H}\right]$ benzylpenicillin, examined in isolated membranes and whole organisms

\begin{tabular}{|c|c|c|c|c|}
\hline \multirow[b]{2}{*}{ Organism } & \multirow{2}{*}{$\begin{array}{c}\text { MIC } \\
\left(\mu \mathrm{g} \mathrm{ml}^{-1}\right)\end{array}$} & \multirow{2}{*}{$\begin{array}{c}\text { PBP } \\
\text { no. }\end{array}$} & \multicolumn{2}{|c|}{$S_{50}\left(\mu \mathrm{g} \mathrm{ml}^{-1}\right)^{*}$} \\
\hline & & & Membranes & Whole organisms \\
\hline S. bovis & 0.036 & $\left.\begin{array}{l}1 \\
2 \\
3 \\
4 \\
5\end{array}\right\}$ & $\begin{array}{l}0.27 \\
0 \cdot 105 \dagger \\
0.25 \dagger \\
0.35\end{array}$ & $\begin{array}{l}0.45 \quad(12.5) \ddagger \\
0.96 \quad(26.7) \\
0.085 \quad(2.4) \\
0.47 \quad(13 \cdot 1) \\
0.76(21 \cdot 1) \\
0.053 \quad(1.5)\end{array}$ \\
\hline S. faecalis & $4 \cdot 8$ & $\begin{array}{l}1 \\
2 \\
3 \\
4 / 5 \dagger \\
6\end{array}$ & $\begin{array}{l}8 \cdot 8 \\
2 \cdot 1 \\
8 \cdot 0 \\
6 \cdot 2 \\
0 \cdot 017\end{array}$ & $\begin{array}{ll}0.83 & (0.17) \\
0.56 & (0.12) \\
0.55 & (0.11) \\
2.3 & (0.48) \\
0.62 & (0.13)\end{array}$ \\
\hline S. faecium & $37 \cdot 2$ & $\left.\begin{array}{l}1 \\
2 \\
3 \\
4 \\
5 \\
6\end{array}\right\}$ & $\begin{array}{c}1 \cdot 5 \\
7 \cdot 8 \\
1 \cdot 7 \\
11 \cdot 2 \dagger \\
4 \cdot 3\end{array}$ & $\begin{array}{ll}1.1 & (0.03) \\
0.15 & (0.00) \\
1.0 & (0.03) \\
4.2 & (0.11) \\
5.6 & (0.15) \\
0.9 & (0.02)\end{array}$ \\
\hline
\end{tabular}

* Concentration of antibiotic required to give $50 \%$ saturation. See Methods for details.

$\dagger$ These PBPs were not sufficiently resolved.

$\ddagger$ Values in parentheses indicate $S_{50}$ values expressed as multiples of the MIC.

strain when exposed to the $\left[{ }^{3} \mathrm{H}\right]$ benzylpenicillin at the MIC, whereas all of the PBPs were evident at the MIC in $S$. faecalis and $S$. faecium.

The loss of $\left[{ }^{3} \mathrm{H}\right]$ benzylpenicillin from the PBP complexes in membranes was also measured in each strain, and the calculated half-lives are presented in Table 2. All of the PBP complexes had observable, but relatively low, rates of breakdown. The addition of neutral hydroxylamine (nucleophilic donor) or 2-mercaptoethanol significantly increased the rates of loss of the antibiotic from all of the PBPs.

The interactions of unlabelled ampicillin and cephalothin with the PBPs were measured by pretreatment of either membranes or whole organisms with the antibiotics, followed by labelling of unbound PBPs with an excess of $\left[{ }^{3} \mathrm{H}\right]$ benzylpenicillin (Table 3). The lower antibacterial 
Table 2. Release of $\left[{ }^{3} \mathrm{H}\right]$ benzylpenicillin from the PBPS

\begin{tabular}{|c|c|c|c|c|}
\hline \multirow[b]{2}{*}{ Organism } & \multirow{2}{*}{$\begin{array}{c}\text { PBP } \\
\text { no. }\end{array}$} & \multicolumn{3}{|c|}{ Time for $50 \%$ release of $\left[{ }^{3} \mathrm{H}\right]$ benzylpenicillin $(\mathrm{min})$} \\
\hline & & No addition & 2-Mercaptoethanol & Hydroxylamine \\
\hline S. bovis & $\begin{array}{l}1 \\
2 / 3^{*} \\
4 / 5^{*} \\
6\end{array}$ & $\begin{array}{l}117 \\
119 \\
189 \\
108\end{array}$ & $\begin{array}{l}28(4 \cdot 2) \dagger \\
57(2 \cdot 1) \\
71(2 \cdot 7) \\
51(2 \cdot 1)\end{array}$ & $\begin{array}{l}37(3 \cdot 2) \dagger \\
89(1 \cdot 3) \\
99(1 \cdot 9) \\
70(1 \cdot 5)\end{array}$ \\
\hline S. faecalis & $\begin{array}{l}1 \\
2 \\
3 \\
4 / 5^{*} \\
6\end{array}$ & $\begin{array}{l}189 \\
209 \\
107 \\
593 \\
255\end{array}$ & $\begin{array}{r}23(7 \cdot 9) \\
34(6 \cdot 1) \\
17(6 \cdot 3) \\
149(4 \cdot 0) \\
83(3 \cdot 1)\end{array}$ & $\begin{array}{c}18(10 \cdot 5) \\
38(5 \cdot 5) \\
30(3 \cdot 6) \\
158(3 \cdot 8) \\
123(2 \cdot 1)\end{array}$ \\
\hline S. faecium & $\begin{array}{l}1 \\
2 / 3^{*} \\
4 / 5^{*} \\
6\end{array}$ & $\begin{array}{l}179 \\
102 \\
716 \\
236\end{array}$ & $\begin{array}{r}42(4 \cdot 3) \\
49(2 \cdot 1) \\
212(3 \cdot 4) \\
\text { ND }\end{array}$ & $\begin{array}{l}57(3 \cdot 1) \\
54(1 \cdot 9) \\
181(4 \cdot 0) \\
\text { ND }\end{array}$ \\
\hline
\end{tabular}

ND, Not determined.

* These PBPs were not sufficiently resolved.

$\dagger$ Values in parentheses indicate extent of increase of rate of release of $\left[{ }^{3} \mathrm{H}\right]$ benzylpenicillin following treatment with 2-mercaptoethanol or hydroxylamine. See Methods for details.

Table 3. Affinities of the PBPs of group D streptococci, examined in isolated membranes and whole organisms, for ampicillin and cephalothin

\begin{tabular}{|c|c|c|c|c|c|c|c|c|c|}
\hline \multirow[b]{2}{*}{ Strain } & \multicolumn{4}{|c|}{ Ampicillin } & \multicolumn{3}{|c|}{ Cephalothin } & \multicolumn{2}{|c|}{$\begin{array}{l}\text { Ratio of } \mathrm{I}_{50} \text { Cepha- } \\
\text { lothin : } \mathrm{I}_{50} \text { Ampicillin }\end{array}$} \\
\hline & $\begin{array}{l}\text { PBP } \\
\text { no. }\end{array}$ & $\begin{array}{c}\mathrm{MIC} \\
\left(\mathrm{nmol} \mathrm{ml}^{-1}\right)\end{array}$ & $\begin{array}{l}\text { Mem- } \\
\text { branes }\end{array}$ & $\begin{array}{c}\text { Whole } \\
\text { organisms }\end{array}$ & $\begin{array}{c}\text { MIC } \\
\left(\mathrm{nmol} \mathrm{ml}^{-1}\right)\end{array}$ & $\begin{array}{l}\text { Mem- } \\
\text { branes }\end{array}$ & $\begin{array}{l}\text { Whole } \\
\text { organisms }\end{array}$ & $\begin{array}{l}\text { Mem- } \\
\text { branes }\end{array}$ & $\begin{array}{l}\text { Whole } \\
\text { organisms }\end{array}$ \\
\hline S. bovis & & $0 \cdot 17$ & & & 0.62 & & & & \\
\hline & 1. & & 0.018 & $0 \cdot 22$ & $(3 \cdot 6) \ddagger$ & 0.019 & 0.07 & $1 \cdot 1$ & 0.3 \\
\hline & $\begin{array}{l}2 \\
3\end{array}$ & & $0.073 \dagger$ & $\begin{array}{l}0.31 \\
0 \cdot 43\end{array}$ & & $0.17 \dagger$ & $\begin{array}{l}0.075 \\
0.4\end{array}$ & $2 \cdot 3$ & $\begin{array}{l}0.2 \\
0.9\end{array}$ \\
\hline & 4 & & $0.048 \dagger$ & $0 \cdot 19$ & & $0.59 \dagger$ & $0 \cdot 11$ & $12 \cdot 3$ & 0.6 \\
\hline & 6 & & 0.023 & $0 \cdot 21$ & & $1 \cdot 40$ & $\begin{array}{l}4 \cdot 2 \\
7 \cdot 8\end{array}$ & $60 \cdot 9$ & $\begin{array}{l}14 \cdot 0 \\
37 \cdot 0\end{array}$ \\
\hline S. faecalis & & $2 \cdot 8$ & & & $153 \cdot 0$ & & & & \\
\hline & 1 & & 0.47 & 1.5 & $(55 \cdot 0)_{\ddagger}^{\ddagger}$ & $4 \cdot 4$ & $13 \cdot 0$ & $9 \cdot 4$ & $8 \cdot 7$ \\
\hline & 2 & & $0 \cdot 19$ & 0.09 & & $0 \cdot 12$ & 0.35 & 0.6 & 3.9 \\
\hline & 3 & & $0 \cdot 19$ & 0.92 & & $1 \cdot 1$ & $8 \cdot 0$ & $5 \cdot 8$ & $8 \cdot 7$ \\
\hline & $4 / 5 \dagger$ & & $0 \cdot 39$ & 0.67 & & $10 \cdot 8$ & $48 \cdot 0$ & $27 \cdot 7$ & $72 \cdot 0$ \\
\hline & 6 & & $254 \cdot 0$ & $22 \cdot 0$ & & $19 \cdot 7$ & $54 \cdot 0$ & $0 \cdot 1$ & $2 \cdot 5$ \\
\hline S. faecium & & $22 \cdot 5$ & & & $1230 \cdot 0$ & & & & \\
\hline & 1 & & 0.19 & 0.42 & $(55.0)$ & 0.31 & $2 \cdot 9$ & 1.6 & 6.9 \\
\hline & $\begin{array}{l}2 \\
3\end{array}$ & & $0 \cdot 19 \dagger$ & $\begin{array}{l}0.064 \\
0.11\end{array}$ & & $0.17 \dagger$ & $\begin{aligned}<0.05 \\
0.064\end{aligned}$ & 0.9 & $<0.8$ \\
\hline & 4 & & 1.4 & 1.9 & & $111 \cdot 0$ & $160 \cdot 0$ & $79 \cdot 3$ & $84 \cdot 0$ \\
\hline & 5 & & $0 \cdot 19$ & 0.76 & & $18 \cdot 7$ & $100 \cdot 0$ & 98.4 & $131 \cdot 0$ \\
\hline & 6 & & $1 \cdot 7$ & $7 \cdot 2$ & & $123 \cdot 0$ & $1400 \cdot 0$ & $72 \cdot 4$ & $194 \cdot 0$ \\
\hline
\end{tabular}

* Concentration of antibiotic required to give $50 \%$ inhibition of the subsequent binding of $\left[{ }^{3} \mathrm{H}\right]$ benzylpenicillin. $\dagger$ These PBPs were not sufficiently resolved.

$\ddagger$ Ratio of MIC of cephalothin to MIC of ampicillin.

effectiveness (higher MIC) of cephalothin in comparison with ampicillin for each organism was reflected by decreased affinities (higher $\mathrm{I}_{50}$ values) to one or more of the lower molecular weight PBPs; this decrease was observed whether the interactions were measured in isolated membranes or whole organisms. 
Table 4. Comparison of the binding of $\left[{ }^{3} \mathrm{H}\right]$ benzylpenicillin to the PBPs of whole organisms and protoplasts

\begin{tabular}{|c|c|c|c|}
\hline \multirow[b]{2}{*}{ Organism } & \multirow[b]{2}{*}{$\begin{array}{c}\text { PBP } \\
\text { no. }\end{array}$} & \multicolumn{2}{|c|}{$S_{50}\left(\mu \mathrm{g} \mathrm{ml}^{-1}\right)^{*}$} \\
\hline & & $\begin{array}{c}\text { Whole } \\
\text { organisms }\end{array}$ & Protoplasts \\
\hline S. bovis & $\begin{array}{l}1 \\
2 \\
3 \\
4 \\
5 \\
6\end{array}$ & $\begin{array}{l}0 \cdot 78 \\
1 \cdot 6 \\
0 \cdot 17 \\
0 \cdot 86 \\
1 \cdot 3 \\
0 \cdot 10\end{array}$ & $\begin{array}{l}0 \cdot 82 \\
1 \cdot 7 \\
0 \cdot 19 \\
0 \cdot 73 \\
1 \cdot 4 \\
0 \cdot 12\end{array}$ \\
\hline S. faecalis & $\begin{array}{l}1 \\
2 \\
3 \\
4 / 5 \dagger \\
6\end{array}$ & $\begin{array}{l}1 \cdot 1 \\
0 \cdot 64 \\
0 \cdot 80 \\
2 \cdot 8 \\
0.97\end{array}$ & $\begin{array}{l}0.95 \\
0.55 \\
0.91 \\
3 \cdot 2 \\
0.91\end{array}$ \\
\hline S. faecium & $\begin{array}{l}1 \\
2 \\
3 \\
4 \\
5 \\
6\end{array}$ & $\begin{array}{l}1 \cdot 7 \\
0.24 \\
1.4 \\
7 \cdot 5 \\
9.3 \\
1.4\end{array}$ & $\begin{array}{l}1.9 \\
0.23 \\
1.5 \\
6.0 \\
7.7 \\
1.6\end{array}$ \\
\hline
\end{tabular}

* Concentration of $\left[{ }^{3} \mathrm{H}\right]$ benzylpenicillin required to give $50 \%$ saturation. See Methods for details.

$\dagger$ These PBPs were not sufficiently resolved.

Table 5. Rate of binding of $\left[{ }^{3} H\right]$ benzylpenicillin to the PBPs of whole organisms and protoplasts

$\begin{array}{llcc}\text { Organism } & \begin{array}{c}\text { PBP } \\ \text { no. }\end{array} & \begin{array}{c}\text { Thole for } 50 \% \\ \text { organisms } \\ \text { saturation }\end{array} & \text { Prin) } \\ \text { S. faecalis } & 1 & 3.9 & 3.6 \\ & 2 / 3^{*} & 2 \cdot 7 & 2 \cdot 5 \\ & 4 / 5^{*} & 3.5 & 3.5 \\ & 6 & 0.8 & 0.8 \\ \text { S. faecium } & 1 & 0.3 & 0.3 \\ & 2 & 0.3 & 0.3 \\ & 3 & 0.3 & 0.3 \\ & 4 / 5^{*} & 6.4 & 5 \cdot 7 \\ & 6 & 1.0 & 0.8\end{array}$

* These PBPs were not sufficiently resolved.

In another series of experiments the accessibilities of the PBPs in whole organisms and protoplasts were compared in parallel. Titration of the $\left[{ }^{3} \mathrm{H}\right]$ benzylpenicillin with samples of whole organisms or protoplasts derived from the same number of bacteria showed that equivalent amounts became bound to the PBPs at each concentration tested (Table 4). Moreover, the total amount bound under saturating conditions was essentially the same in each case (data not shown). The rates of binding of the $\left[{ }^{3} \mathrm{H}\right]$ benzylpenicillin to the various PBPs of each organism under saturating conditions were also compared in whole organisms and protoplasts (Table 5), and again were virtually identical.

\section{DISCUSSION}

Several distinct mechanisms may be responsible for penicillin resistance in bacteria. The first mechanism, production of a $\beta$-lactamase, has not been identified in enterococci (Weinstein $\&$ 
Moellering, 1975). A second mechanism of penicillin resistance involves the presence of a permeability barrier between the $\beta$-lactam antibiotic in the growth medium and the target enzymes in the bacterial cell membrane. Such a mechanism has recently been shown to be of major importance in the resistance of Pseudomonas aeruginosa to $\beta$-lactam antibiotics (Zimmerman, 1980). A third mechanism of penicillin resistance involves alteration of the affinities of the target enzymes. This mechanism of resistance is found in penicillin-resistant clinical isolates of S. pneumoniae (Hakenbeck et al., 1980; Zighelboim \& Tomasz, 1980), intrinsically penicillin-resistant Neisseria gonorrhoeae (Dougherty et al., 1980), and methicillinresistant Staphylococcus aureus (Hartman \& Tomasz, 1981). We wished to distinguish decreased permeability to $\beta$-lactam antibiotics from diminished affinity of the target enzymes as the mechanism of penicillin resistance in enterococci.

The use of high specific activity $\left[{ }^{3} \mathrm{H}\right]$ benzylpenicillin allowed sensitive labelling of PBPs both in isolated cell membranes and in actively growing bacterial cells. Using this reagent we characterized the PBPs of three strains of group D streptococci. Though each strain had six major PBPs, the pattern differed in each strain. The possibility of using PBP patterns for taxonomic purposes has already been suggested (Georgopapadakou \& Liu, 1980a).

Comparisons of the PBP patterns of our $S$. faecalis and $S$. faecium strains with the PBP patterns of group D streptococci reported in the literature require comment because of taxonomic confusion. The strain of $S$. faecalis (447) used in this study showed the fermentation reactions typical of this species and exhibited the expected difference from $S$. faecium in taxonomic tests. The molecular weights of the PBPs in strain 447 of $S$. faecalis as well as in two other independent clinical isolates from the Veterans Administration Hospital, New York (unpublished data) corresponded closely to those previously reported by Georgopapadakou \& Liu $(1980 \mathrm{~b})$, with the exceptions that we detected two PBPs (4 and 5) in the vicinity of the PBP 4 of $S$. faecalis SC 9011 , and we did not detect the 35000 molecular weight protein. On the other hand, the molecular weights of PBPs from S. faecalis (447) or S. faecalis SC 9011 are clearly different from those described by Coyette et al. (1978) and Fontana et al. (1980) in S. faecalis ATCC 9790, which was very similar to the PBP pattern from S. faecium (4379) and another clinical isolate of this species (unpublished data). Strain ATCC 9790 was designated $S$. faecium var. durans by Smith (1970) and is listed in current editions of the American Type Culture Collection as $S$. faecium ATCC 9790; the PBP patterns are consistent with such a designation.

However, the MIC for benzylpenicillin of strain ATCC 9790 is low by comparison with most clinical isolates of $S$. faecium. Penicillin MIC values $\left(\mu \mathrm{g} \mathrm{ml}^{-1}\right)$ for ATCC 9790 have been reported as 0.04 (at $45^{\circ} \mathrm{C}$ in synthetic medium), 0.7 (at $37^{\circ} \mathrm{C}$ in rich medium), and 4.0 (at $32^{\circ} \mathrm{C}$ in synthetic medium). By comparison, $S$. faecium (4379) had a penicillin MIC of $37 \cdot 2 \mu \mathrm{g} \mathrm{ml}^{-1}$ which is well within the range reported for most clinical isolates of this species (Moellering et al., 1979). The MIC values of $S$. faecalis (447) and two strains of $S$. faecalis from the Veterans Administration Hospital (New York) were 4.8, 2.7 and $2.7 \mu \mathrm{g} \mathrm{ml}^{-1}$, respectively, again within the range characteristic of isolates of this species. The anomalously low penicillin MIC value of strain ATCC 9790 is reminiscent of the behaviour of a penicillin-hypersensitive $S$. faecium mutant (G. Eliopoulos, C. Wennersten \& R. C. Moellering, Jr, unpublished findings), in which the penicillin MIC was $0.06 \mu \mathrm{g} \mathrm{ml}^{-1}$ compared with $32 \mu \mathrm{g} \mathrm{ml}^{-1}$ for the parental strain.

In the present study, the molecular weights of PBPs observed in isolated cell membranes and in actively growing bacterial cells of the same strain were identical. On the other hand, significant differences were noted between the penicillin 'affinities' of PBPs as labelled in vitro (in membranes) versus in vivo (in growing cells) particularly in the case of the $S$. faecalis isolate. In general, substantially higher concentrations of $\left[{ }^{3} \mathrm{H}\right]$ penicillin were needed to achieve half saturation of a PBP in vitro as compared to in vivo. This anomaly may be related to some alteration of the PBPs during membrane preparation or to the substantially higher concentration of membrane protein $\left(20 \mu \mathrm{g} \mathrm{m}^{-1}\right)$ used in the in vitro assays, relative to the corresponding membrane protein concentration in the in vivo labelling experiments $\left(2 \times 10^{8}\right.$ cells, or about $5-10 \mu \mathrm{g}$ membrane protein $\mathrm{ml}^{-1}$ ). A similar anomaly has been noted in other bacteria (Chase et al., 1981; Gutmann et al., 1981). In sharp contrast to the discrepancies described above, virtually identical PBP titration profiles were obtained when the PBPs were labelled in a parallel experiment utilizing equal numbers of intact cells and protoplasts. 
All of the PBPs formed stable complexes with benzylpenicillin, with relatively long half-times of dissociation. The value of PBP 6 in S. faecium (4379) $(236 \mathrm{~min})$ correlates well with the value of $265 \mathrm{~min}$ for this PBP previously reported by Coyette et al. (1978). Mercaptoethanol and hydroxylamine stimulated the release of $\left[{ }^{3} \mathrm{H}\right]$ penicillin from the PBP complexes.

Although there was a roughly inverse correlation between the MIC value and the total amount of benzylpenicillin bound to the streptococcal membranes exposed to the same concentration of [ $\left.{ }^{3} \mathrm{H}\right]$ penicillin (Fig. 2), the $\mathrm{S}_{50}$ values of individual PBPs showed poor correlation with the MIC and there was variation both within a strain and between strains. In $S$. bovis (4054), for example, only 2 PBPs were detected at benzylpenicillin concentrations equal to the MIC. In S. faecium (447), on the other hand, all of the PBPs showed $50 \%$ binding at concentrations of benzylpenicillin well below the MIC. Even in cultures of actively dividing whole cells there was no satisfactory correlation between $\mathrm{S}_{50}$ and MIC values of the strains.

Fontana et al. (1980) recently showed that the MIC of benzylpenicillin for ATCC $9790(S$. faecium var. durans) was 100 -fold less when the strain was grown at $45^{\circ} \mathrm{C}$ as compared to $32^{\circ} \mathrm{C}$. At this higher temperature only PBP 3 bound benzylpenicillin when incubated with a concentration equal to the lowered MIC. It was postulated, therefore, that PBP 3 may be the 'killing target' of this bacterium when grown at $45^{\circ} \mathrm{C}$. A unique killing site of benzylpenicillin for enterococci was not found in the present study. Indeed, the $S_{50}$ values of all six PBPs of $S$. faecium were dramatically lower than the corresponding MIC. It seems likely that measurement of such $\mathbf{S}_{50}$ values, even in whole bacteria, does not yield a quantitative correlation with inhibition of cell growth by the antibiotic.

Recently, a strain of $S$. faecium sensitive to benzylpenicillin has been derived by novobiocin treatment of the same $S$. faecium strain used in these experiments (G. Eliopoulos, C. Wennersten \& R. C. Moellering Jr, unpublished findings). Interestingly, the PBPs of the penicillin sensitive strain showed nearly identical penicillin binding to those of the penicillin resistant parent. In other words, the same degree of PBP saturation that was associated with inhibition of cell growth in one strain, had no measurable effect on the other. Still another example for the lack of direct, quantitative correlation between antibiotic binding to PBPs and the antibiotic sensitivity of the corresponding bacterium has been noted in studies with methicillin-resistant staphylococci (Hartman \& Tomasz, 1981). The 1000-fold increase in the phenotypic methicillin sensitivity (MIC change from 3200 to $0.4 \mu \mathrm{g} \mathrm{ml}^{-1}$ ) observable during growth of the methicillin resistant $S$. aureus in media with a low $\mathrm{pH}$ value, was not accompanied by the expected parallel change (increase) in PBP affinity for methicillin.

To further examine potential differences in PBP affinities between the three strains of group $D$ streptococci, we investigated the effects of pretreatment of either isolated membranes or intact bacteria with either ampicillin or cephalothin; PBPs remaining unbound after the pretreatment were detected by adding a saturating amount of $\left[{ }^{3} \mathrm{H}\right]$ benzylpenicillin. These antibiotics were chosen because the MIC values of cephalosporins for enterococci are much higher than those of ampicillin. Again there was poor correlation of the $I_{50}$ values of individual PBPs with the ampicillin and cephalothin MIC values. For example, PBP 2 of $S$. faecalis showed high cephalothin affinity (as reflected in a low $\mathrm{I}_{50}$ value), despite the very high cephalothin MIC; this discrepancy has been previously noted by Georgopapadakou \& Liu (1980 b). For other PBPs, however, particularly the lower molecular weight PBPs of the enterococci, cephalothin showed much poorer affinity. We expressed PBP binding for cephalothin in relation to ampicillin as the ratio of the respective $I_{50}$ values. As seen in the last two columns of Table 3, the value of this ratio for certain lower molecular weight PBPs correlated roughly with the ratio of cephalothin to ampicillin MIC values. For example, in $S$. faecium, the $\mathrm{I}_{50}$ ratios for PBPs 4,5 and 6 correlate roughly with the MIC ratio of 55 . These data suggest the possibility that diminished cephalothin binding to selected lower molecular weight PBPs in group D streptococci may relate in a general way to its diminished antibacterial effectiveness in comparison with ampicillin.

When the same numbers of whole organisms and protoplasts were exposed to various concentrations of $\left[{ }^{3} \mathrm{H}\right]$ benzylpenicillin there was no difference in binding to individual PBPs at the concentrations of penicillin tested. Furthermore, there were no differences in the total amount of $\left[{ }^{3} \mathrm{H}\right]$ benzylpenicillin bound to each PBP at saturation (data not shown), nor in the half-times of 
the rates of penicillin binding. These findings conclusively demonstrated that the bacterial cell wall of group D streptococci imposed no permeability barrier to the penetration of penicillin $G$. Gutmann et al. (1981) have recently documented the similar absence of a permeability barrier to penicillin in group A streptococci using parallel labelling of the PBPs in whole organisms and in crude lysates.

In summary, the experiments described seem to explode the possibility that variations in a permeability barrier of the bacterial wall are responsible for the high and varying MIC values of $\beta$-lactam antibiotics for group D streptococci. Our data indicate that the sensitivity to these antibiotics is related to the antibiotic affinities of the PBPs. However, a quantitative correlation between MIC values and corresponding PBP binding was not demonstrable in membrane preparations or during labelling of the PBPs in live bacteria.

While labelling of PBPs in vivo clearly represents a more realistic experimental design than labelling of isolated membrane preparations, it should be remembered that the MIC value is a function of antibiotic dose (i.e. concentration multiplied by time of exposure) rather than antibiotic concentration alone. It is conceivable that the establishment of a quantitative correlation between MIC and PBP saturation would require studies in which binding to the PBPs was determined during exposure times long enough to cause a morphological effect (Chase et al., 1981), or inhibition of growth and peptidoglycan synthesis (R. Williamson \& A. Tomasz, unpublished findings).

This study was supported by Public Health Service grant AI 16170 from the National Institutes of Health (to A. T.). S.C. was a recipient of a research fellowship grant (AI 06074) from the National Institute of Allergy and Infectious Disease, and R.W. was supported by a Merck Research Fellowship. We thank Kathleen Gross for characterization of the group D streptococci used in this study and Drs James Rahal and David Simberkoff of the Veterans Administration Hospital, New York, for two strains of $S$. faecalis.

\section{REFERENCES}

Chase, H. A., Fuller, C. \& Reynolds, P. E. (1981). The role of penicillin-binding proteins in the action of cephalosporins against Escherichia coli and Salmonella typhimurium. European Journal of Biochemistry 117, 301-310.

Coyette, J., Ghuysen, J. \& Fontana, R. (1978). Solubilization and isolation of the membrane-bound DD-carboxypeptidase of Streptococcus faecalis ATCC 9790. European Journal of Biochemistry 88, 297-305.

Dougherty, T. J., Koller, A. E. \& Tomasz, A. (1980). Penicillin-binding proteins of penicillinsusceptible and intrinsically resistant Neisseria gonorrhoeae. Antimicrobial Agents and Chemotherapy 18, $730-737$.

FACKLAM, R. R. (1972). Recognition of group D streptococcal species of human origin by biochemical and physiological tests. Applied Microbiology 23, 1131-1139.

Fontana, R., Canepari, P., Satta, G. \& Coyette, J. (1980). Identification of the lethal target of benzylpenicillin in Streptococcus faecalis by in vivo penicillin binding studies. Nature, London 287, 70-72.

GeORGOPAPADAKOU, N. H. \& LIU, F. Y. $(1980 a)$. Penicillin-binding proteins in bacteria. Antimicrobial Agents and Chemotherapy 18, 148-157.

GeORgopapadakou, N. H. \& LiU, F. Y. (1980b). Binding of $\beta$-lactam antibiotics to penicillin-binding proteins of Staphylococcus aureus and Streptococcus faecalis: relation to antibacterial activity. Antimicrobial Agents and Chemotherapy 18, 834-836.
Gross, K. C., Houghton, M. P. \& Senterfit, L. B. (1975). Presumptive speciation of Streptococcus bovis and other group D streptococci from human sources by using arginine and pyruvate tests. Journal of Clinical Microbiology 1, 54-60.

GutmanN, L., Williamson, R. \& Tomasz, A. (1981). Physiological properties of penicillin-binding proteins in group A streptococci. Antimicrobial Agents and Chemotherapy 19, 872-880.

Hakenbeck, R., TARPay, M. \& Tomasz, A. (1980). Multiple changes of penicillin-binding proteins in penicillin-resistant clinical isolates of Streptococcus pneumoniae. Antimicrobial Agents and Chemotherapy 17, 364-371.

Hartman, B. \& Tomasz, A. (1981). Altered penicillinbinding proteins in methicillin-resistant strains of Staphylococcus aureus. Antimicrobial Agents and Chemotherapy 19, 726-735.

Krogstad, D. J. \& Parquette, A. R. (1980). Defective killing of enterococci : a common property of antimicrobial agents acting on the cell wall. Antimicrobial Agents and Chemotherapy 17, 965-968.

Moellering, R. C., JR (1981). Antimicrobial susceptibility of enterococci : in vitro studies of the action of antibiotics alone and in combination. In Treatment of Infective Endocarditis, pp. 81-96. Edited by A. L. Bisno. New York: Grune and Stratton.

Moellering, R. C., JR, Watson, B. K. \& KUnz, L. J. (1974). Endocarditis due to group D streptococci. American Journal of Medicine 57, 239-250. 
Moellering, R. C., JR, Korzeniowski, O. M., SANDE, M. K. \& WenNersten, C. B. (1979). Speciesspecific resistance to antimicrobial synergism in Streptococcus faecium and Streptococcus faecalis. Journal of Infectious Diseases 140, 203-208.

Siegel, J. L., Hurst, S. F., Liberman, E. S., Coleman, S. E. \& Bleiweis, A. S. (1981). Mutanolysin-induced spheroplasts of Streptococcus mutans are true protoplasts. Infection and Immunity 31, 808-815.

SmITH, D. G. (1970). The identity of Streptococcus faecalis ATCC 9790. Journal of Applied Bacteriology 33, 474-477.

Thornsberry, C., Baker, C. N. \& FaCKLaM, R. R. (1974). Antibiotic susceptibility of Streptococcus bovis and other group D streptococci causing endocarditis. Antimicrobial Agents and Chemotherapy 5, 228-233.

Toala, P., McDonald, A., Wilcox, C. \& Finland, M. (1969). Susceptibility of group D streptococcus (enterococcus) to 21 antibiotics in vitro, with special reference to species differences. American Journal of Medical Science 258, 416-430.

Weinstein, A. J. \& Moellering, R. C., JR (1975). Studies of cephalothin: aminoglycoside synergism against enterococci. Antimicrobial Agents and Chemotherapy 7, 522-529.

Williamson, R., Hakenbeck, R. \& Tomasz, A. (1980). The penicillin-binding proteins of Streptococcus pneumoniae grown under lysis-permissive and lysisprotective (tolerant) conditions. FEMS Microbiology Letters 7, 127-131.

Zighelboim, S. \& Tomasz, A. (1980). Penicillinbinding proteins of multiply antibiotic-resistant South African strains of Streptococcus pneumoniae. Antimicrobial Agents and Chemotherapy 17, 434-442.

Zimmerman, W. (1980). Penetration of $\beta$-lactam antibiotics into their target enzymes in Pseudomonas aeruginosa: comparison of a highly sensitive mutant with its parent strain. Antimicrobial Agents and Chemotherapy 18, 94-100. 